\title{
Active botanical biofiltration of air pollutants using Australian native plants
}

\author{
Naomi J. Paull ${ }^{\mathrm{a}}$, Peter J. Irga ${ }^{\mathrm{b} *}$, Fraser R. Torpy ${ }^{\mathrm{a} *}$ \\ a Plants and Environmental Quality Research Group, School of Life Sciences, Faculty of Science, \\ University of Technology Sydney, P.O. Box 123, Broadway, Sydney, NSW, 2007, Australia \\ ${ }^{\mathrm{b}}$ Plants and Environmental Quality Research Group, School of Civil and Environmental Engineering, \\ Faculty of Engineering and Information Technology, University of Technology Sydney, Australia \\ *Corresponding authors. Peter.Irga@uts.edu.au, Fraser.Torpy@uts.edu.au
}

\section{Keywords}

Australian native plants, single pass removal efficiency, green walls, indoor phytoremediation, green buildings, sustainability

\begin{abstract}
Air pollutants are of public concern due to their adverse health effects. Biological air filters have shown great promise for the bioremediation of air pollutants. Different plant species have previously been shown to significantly influence pollutant removal capacities, although the number of species tested to date is small. The aim of this paper was to determine the pollutant removal capacity of different Australian native species for their effect on active biowall particulate matter, volatile organic compounds and carbon dioxide removal, and to compare removal rates with previously tested ornamental species. The single pass removal efficiency for PM and VOCs of native planted biofilters was determined with a flow through chamber. $\mathrm{CO}_{2}$ removal was tested by a static chamber pull down study. The results indicated that the native species were not effective for $\mathrm{CO}_{2}$ removal likely due to their high light level requirements in conjunction to substrate respiration. Additionally, the native species had lower PM removal efficiencies compared to ornamental species, with this potentially being due to the ornamental species possessing advantageous leaf traits for increased PM accumulation. Lastly, the native species were found to have similar benzene removal efficiencies to ornamental species. As such, whilst the native species showed a capacity to phytoremediate air pollutants, ornamental species have a comparatively greater capacity to do so and are more appropriate for air filtration purposes in indoor circumstances. However, as Australian native plants have structural and metabolic adaptations that enhance their ability to tolerate harsh environments, they may find use in botanical biofilters in situations where common ornamental plants may be suitable, especially in the outdoor environment.
\end{abstract}




\section{Introduction}

Phytoremediation involves the utilization of plants and their associated microbial communities to ameliorate pollution, and is generally considered as an environmentally friendly and economical technology. The application of phytoremediation for air purification originated with investigations by Wolverton and colleagues (Wolverton et al. 1984), who demonstrated the capability of foliage plants for purifying VOC-contaminated air. Subsequently, the biological activity of plant and substrate microflora has been shown to be capable of reducing various air pollutants including $\mathrm{CO}_{2}$ (Irga et al. 2013; Torpy et al. 2014; Su \& Lin 2015), particulate matter (PM) (Lohr \& Pearson-Mims, 1996; Gawrońska and Bakera, 2015); ozone (Abbass et al. 2017) and volatile organic compounds (VOCs) (Godish \& Guindon, 1989; Wolverton \& Wolverton, 1993; Wood et al. 2002; Orwell et al. 2004; Wood et al. 2006; Aydogan \& Montoya, 2011; Irga et al. 2013; Torpy et al. 2013).

Different characteristics of plants are known to influence their suitability for air phytoremediation (Lin et al. 2017). Variation in shapes, volume of crown, leaf macro- and micromorphology, leaf size, and cuticular waxes are important traits that must be considered for efficient air pollutant removal (Litschke and Kuttler, 2008; Petroff et al. 2008; Ram et al. 2012; Sæbo et al. 2012; Chen et al. 2016; Leonard et al., 2016). Whilst there are a number of studies linking air pollutant removal to effects restricted to plant behaviour, (Singh \& Verma, 2007; Fowler, 2002; Hosker \& Lindberg, 1982; Ottelé et al. 2010; Sternberg et al. 2010) it is widely thought that the performance of botanical air filtration can largely be attributed to rhizospheric microbial activities (Wood et al. 2002; Kim et al. 2010; Pettit et al. 2017).

Conventionally, most built environment solutions to deal with air pollution involves filtration, especially with indoor air and office buildings which are mechanically ventilated. The filters used within these systems have varying levels of particulate matter removal efficiency, but are unable to remove gaseous pollutants other than by dilution with outdoor air. Alternate filter systems have shown to be somewhat more efficient, however they have higher maintenance needs, use a greater amount of energy (Montgomery et al. 2012) and in many cases remain ineffective for gaseous pollutant removal (Torpy et al. 2015). The use of plants as phytoremediators allows not only the effective simultaneous removal of multiple air pollutants; but with development, provides the potential to be cost effective, energy efficient and suitable for long term usage (Torpy et al. 2015).

Building on the 30+ years of studies investigating the use of potted plants to remove air pollutants, and advancements in the field of air phytoremediation, has led to the development of active green walls (also known as active plant walls, functional green walls, phytosystems and botanical biofilters). Green walls are vertical structures in which one or several plant species are grown on a soil or a soilless support fabric or growth medium. Apart from being aesthetically pleasing, green walls provide environmental, social, and economic benefits which can be attributed to their design, plant choice, density of vegetation, and location (Beecham et al. 2019). Green walls have shown to be able to remove VOCs (Darlington et al. 2001; Wang et al. 2014; Wang and Zhang, 2011; Lee et al. 2015 and Chen et al. 2005), PM (Irga et al. 2017; Pettit et al. 2017) and $\mathrm{CO}_{2}$ (Torpy et al. 2016). Currently this technology is being developed by numerous research groups and companies, as such, several active botanical biofilters have been developed. Although these systems differ in design, they all use active airflow using devices such as impellers that increase the airflow to the active components of the systems and therefore allow larger volumes of air to be processed. Many questions remain however, especially regarding pollutant removal efficiencies that may arise due to plant species specific differences.

The selection of plant species has been shown to be influential on the overall VOC, $\mathrm{PM}$ and $\mathrm{CO}_{2}$ removal capacity of active green walls (Torpy et al. 2014). Regarding VOC removal, rhizospheric bacteria are the primary sources for VOC removal (Wood et al. 2002); however, plant associated effects also play a role in VOC removal as shown by Irga et al. (2017). In static potted plant experiments, plant selection has shown to have an influence on VOC removal (Kim et al. 2010); however, the specific plant features influential on VOC removal remain unclear. Nonetheless, certain groups of plants have 
shown the potential for higher VOC removal (Kim et al. 2016). Pettit et al. (2017) examined the influence of plant species on active green wall PM single pass removal efficiency (SPRE), focusing on the anatomical components of different plant species that correlated with improved SPRE. Fern species recorded the highest removal efficiencies across a range of particle size fractions. Upon assessing plant morphological data, it was found that the plant root structure most strongly influenced removal efficiency, probably due to the manner in which different root systems affect the substrate matrix.

Botanical biofilters provide promising potential for reductions in ambient $\mathrm{CO}_{2}$, which could be of use in indoor environments, where a large proportion of the energy consumed by existing mechanical ventilation systems is used for $\mathrm{CO}_{2}$ dilution (Redlich et al. 1997). Different plant species have strongly variant efficiencies for photosynthetic $\mathrm{CO}_{2}$ removal, due both to differing requirements for light, along with different intrinsic photosynthetic rates per unit of leaf area, which interacts with the average leaf area per plant that can be functionally fit into vertical garden systems for different plant species (Torpy et al. 2016). For example, Torpy et al. (2016) showed that Chlorophytum comosum removed $13 \%$ of chamber $\mathrm{CO}_{2}$ at a light intensity of $50 \mathrm{~mol} \mathrm{~m}^{2} \mathrm{~s}^{1}$ photosynthetically active photon density, whist Epipremnum aureum removed $<1 \%$. At an increased light level of $100 \mu \mathrm{mol} \mathrm{m} \mathrm{m}^{2} \mathrm{~s}^{1}$ Chlorophytum removed $20 \%$ of chamber $\mathrm{CO}_{2}$, whilst Epipremnum removed only $8 \%$, highlighting the importance of species selection for effective pollutant removal under specific conditions.

Currently, significant development of active green wall technology is being conducted in Australia. Australia's climate is highly variable, whilst being relatively warm and dry, which has significantly influenced Australian native plant species evolutionary traits. Australian native plants are also subject to a scarcity of essential abiotic factors including water and nutrients. Due to the very low phosphorous availability in Australian soils (Kooyman et al. 2017); many species have developed genetic adaptations to survive (Sulpice et al. 2014). Many Australian native plants have a range of water conservation traits (Wright et al., 2001) and nitrogen fixating capabilities (Sprent et al. 2017). Many Australian native species have evolved a high level of drought tolerance, through small evergreen leaves, high root biomass and high leaf mass per unit area, and stomata adapted to water use efficiency in water limited environments, indicative of drought tolerance (Ullmann, 1989; Brodribb \& Hill, 1993; Pasquet-Kok et al. 2010), all traits associated with water conservation (Schenk \& Jackson, 2002; Thompson, 2005). Due to these characteristics, it is plausible that Australian native species may be suitable for green wall development internationally, due to their capacity to grow in unfavourable environmental conditions, survival under low nutrient conditions, reduced watering requirements, and ability to survive dry spells that may occur in outdoor applications, or due to maintenance failure indoors.

Previous research examining plant species differences in active green wall pollutant removal have been limited to common ornamental species. As the green infrastructure industry becomes more water conscious, locally focused and 'ecofriendly', there is a growing interest in the use of Australian native species for urban greening. To date, however, the pollutant removal capacity of Australian natives and their general suitability for phytoremediation purposes is unknown. The aim of this paper therefore, was to determine the role played by Australian native species for active botanical biofilter $\mathrm{CO}_{2}, \mathrm{PM}$ and VOC removal, and to compare these removal rates to previously tested ornamental species; and thus to determine whether the native species were appropriate for phytoremediation use. 


\section{Method}

\subsection{Active Botanical Biofiltration System}

The current study used an active green wall system (The Junglefy Breathing Wall, Junglefy Pty, Sydney Australia) which has been described previously (Irga et al. 2017). Briefly, the system utilises $0.25 \mathrm{~m}^{2}$ $(500 \times 500 \times 130 \mathrm{~mm})$ modules, and is made from recycled plastic. Each module has 16 compartments for individual plant insertion. Plants are grown in a coconut fibre-based substrate (total of $25 \mathrm{~L}$ per module) enclosed in a high density polyethylene mesh. At the back of each module a small electric axial impeller (72 $\mathrm{mm}$ in diameter) was attached, which provided a total air flow of $14.90 \mathrm{~L} / \mathrm{s}$ passing through the substrate (Abdo et al. 2016). The use of the axial impeller allows for both increased gaseous pollutant and particulate matter removal through the substrate and plant root components.

\subsection{Plant Species}

The plants had been nursery grown for 6 months prior to testing. All tested plants were healthy upon visual inspection, roughly the same size and of the stock that is currently implemented in commercial green walls. Plants were supplied by Junglefy Pty (Sydney). There were inconsistencies both between and within species for biomass variables such as leaf area and height, however the test plants are representative of the expected performance of the green wall modules used in situ, thus these inconsistencies are innate to the system. Plants were supplied in a substrate volume and type that were consistent across species modules and representative of in situ application. All plant modules were watered to field capacity and allowed to drain prior to testing. All testing was conducted between 0900 and 1700 which is when natural photosynthetic activity normally occurs. When not being tested, all modules were maintained on the university's rooftop, with all plants exposed to the same daily environmental conditions, including ambient light conditions and watered the same amount weekly. The plant species chosen were common Australian native species that display growth habits indicating suitability for green wall applications (Table 1). As biofilters containing substrate and plants have been previously shown to remove a greater amount of PM in comparison to substrate only modules (Lee et al. 2015; Irga et al. 2017; Pettit et al. 2017).

Table 1: The Australian native plant species used for the pollutant removal efficiency tests.

\begin{tabular}{|c|c|c|c|}
\hline Species Name & Common Name & Clade & Image \\
\hline $\begin{array}{l}\text { Blechnum gibbum } \\
\text { (Labill.) Mett. }\end{array}$ & Silver lady & Monilophyte & \\
\hline $\begin{array}{l}\text { Callistemon } \\
\text { citrinus (Curtis) } \\
\text { Skeels }\end{array}$ & Bottlebrush & Eudicot & \\
\hline
\end{tabular}




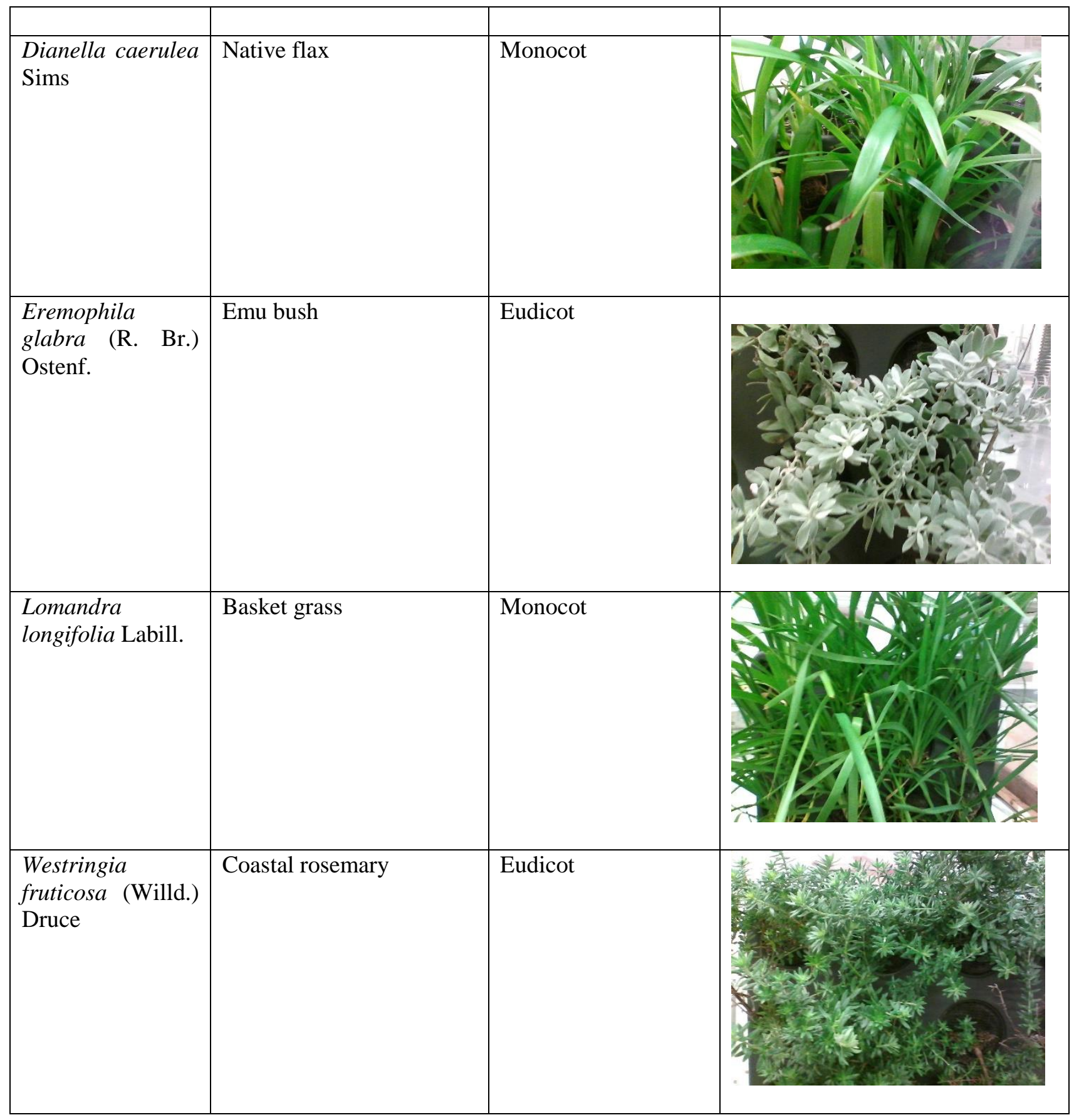

\subsection{Single Pass Removal Efficiency Chamber}

For the determination of VOC and PM removal efficiencies, a flow through chamber was used, previously described in Irga et al. (2019). In brief, the modules were placed in a sealed Perspex chamber $\left(0.6 \mathrm{~m}^{3} ; 216 \mathrm{~L}\right)$. Ducting connected the chamber's front facing side to a second smaller chamber, where pollutants were generated. A $100 \mathrm{~mm}$ diameter $16 \mathrm{~W}$ fan was connected to the port on the back of the module to facilitate pollutant flow through the biofilter. A $40 \mathrm{~mm}$ electric fan was situated within the Perspex chamber to circulate and homogenize the pollutant concentration. Attached to the back of the Perspex chamber was additional ducting leading into a $15 \mathrm{~L}$ Perspex chamber which housed the pollutant recording device. The filtered air was then removed through a vacuum exhaust.

The single pass removal efficiency is determined by the percentage of pollutant that is removed from the air stream by the biofilter in relation to a control treatment. The control treatment was determined 
using the same process, but without any biofilter present inside the chamber. This data was used to calculate any background pollutant removal efficiency caused by the flow through apparatus.

The following equation was used to determine the SPRE:

$\operatorname{SPRE}(\%)=\left[\left(\right.\right.$ Pollutant amount $_{\text {control }}-$ Pollutant amount $\left._{\text {trial }}\right) /$ Pollutant amount $\left._{\text {control }}\right] \times 100$

\subsection{VOC trials}

To determine the native species VOC removal capacity the same method described in Irga et al. (2019) was applied. In brief, gaseous benzene was used as the VOC in this experiment (solubility at $25^{\circ} \mathrm{C}=\sim$ $1 / 71 \mathrm{~g} / \mathrm{L}$ ). $4.0 \mathrm{~mL}$ of the liquid benzene was poured into a $10 \mathrm{~mL}$ sealed glass vial and allowed to stabilize for 24 hours. $2.5 \mathrm{~mL}$ of the VOC saturated vapour located within the headspace of the vial was removed with a gas chromatograph plunger syringe and injected into the pollution generation chamber such that the vaccum created by the in-duct fan passed the VOC through the system. The concentration of the benzene after passing through the biofilter was then monitored for a 10 minute period using a photo-ionisation detector (PID; ppbRAE 3000, RAE Systems, San Jose, CA, USA). This process was repeated 4 times for each species.

\subsection{PM trials}

To determine the native species PM removal capacity the same method used by Pettit et al. (2017) was applied. In brief, PM was generated by burning $4 \mu \mathrm{L}$ of filtered retail grade diesel fuel (Shell) absorbed onto a $1 \mathrm{~cm}^{2} 536: 201280 \mathrm{gsm}$ square piece of paper in the pollution generating chamber. In the pollutant detecting chamber a laser nephelometer (Graywolf PC-3016A, Greywolf Sensing Solutions, Connecticut, USA) was used to record the average PM density and size distribution for a 10 minute period. The average PM concentration was recorded for each of the following PM size fractions: $\mathrm{PM}_{0.3-}$ 0.5, $\mathrm{PM}_{0.5-1.0}, \mathrm{PM}_{1.0-2.5}, \mathrm{PM}_{2.5-5.0}$ and $\mathrm{PM}_{5.0-10.0}$ and total suspended particles (TSP). This process was repeated 15 times for each different species.

\section{$2.6 \mathrm{CO}_{2}$ chamber trials}

To determine the $\mathrm{CO}_{2}$ removal capacity of Australian native species, the method used by Torpy et al. (2016) was applied. All testing was conducted in a $216 \mathrm{~L}$ air tight perspex chamber containing a $40 \mathrm{~mm}$ electric fan to circulate air. Plant species were tested one at a time, with 3 independent replicates per species. The light source used was a $90 \mathrm{~W} / 0.4$ A red-blue plant growth specific LED array which contained a ratio of 2:1 red to blue LEDs, with a total of 90 LEDs ('UFO' grow light, China). This lighting has been shown to provide an adequate spectrum of light for plant growth (Massa et al., 2008). Photosynthetic photon flux density was measured using an Apogee quantum sensor (Apogee Instruments, UT, USA). The light level in the current study ranged from $1505.5 \mu \mathrm{mol} \mathrm{m}^{-2} \mathrm{~s}^{-1}$ at the uppermost level of the foliage of the green wall to $111.6 \mu \mathrm{mol} \mathrm{m}^{-2} \mathrm{~s}^{-1}$ at the bottom of the green wall. This light was selected as it approximated the maximum light level achievable in an indoor setting, such as directly next to a full height glass was, in direct sunlight. For each trial, the starting $\mathrm{CO}_{2}$ concentration within the chamber was $>1000$ ppmv, which is the ASHRAE (2011) recommended maximum for air conditioned buildings. The $\mathrm{CO}_{2}$ concentration was monitored using an Infra-Red Gas Analyser (IRGA; TSI IAQ-CALC, TSI Inc., MN, USA) which was sealed inside the chamber. The test was allowed to run for 40 minutes, as after this period the drawdown of $\mathrm{CO}_{2}$ becomes nonlinear (Torpy et al. 2014). Chamber leakage control treatments for the $\mathrm{CO}_{2}$ removal trials used chambers with a starting

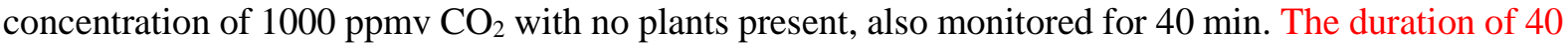
minutes was chosen based on previous studies (Torpy et al. 2014) determining that after the 40 minute duration the rate of $\mathrm{CO}_{2}$ removal no longer became exponential and the relative humidity conditions increased to a point that effected $\mathrm{CO}_{2}$ conditions. Substrate only / no plant treatments were also used to allow separation of the effects of substrate respiration from plant photosynthetic activity or respiration. 


\subsection{Morphological Traits}

Once the chamber tests had been completed, the plants were removed from the module and the substrate washed from the roots. Plant morphological characteristics were then recorded to determine if they were influential on either VOC or PM removal. Four individual plants of each species were used as replicates for each trait.

Digital callipers were used to determine the root and leaf diameters, recording 4 composite measurements per plant across the 4 replicate plants. The root and leaf fresh and dry weights were recorded using a 4 decimal place scale. Dry weights were recorded after the samples have been oven dried for 7 days at $60{ }^{\circ} \mathrm{C}$. Root and leaf areas were determined using a leaf area machine (Licor LI3000-A, Nebraska, USA).

\subsection{Statistical Analysis}

The data was checked for homogeneity of variance using a Levene's test and checked for normality with a Kolmogorov-Smirnov test. A one factor ANOVA and Tukey's post hoc test (IBM SPSS Statistics Version 21, IBM Corp, Armonk, NY, USA) was used to determine differences in species PM and VOC SPREs. A one factor ANOVA and Tukey's post hoc test (IBM SPSS Statistics Version 21, IBM Corp, Armonk, NY, USA) was used to determine differences amongst leaf and root morphologies. Pearson correlations were used to determine the strength of the association of the different plant traits' influence on $\mathrm{CO}_{2}$, VOC and PM removal. To compare the native species capacity to remove $\mathrm{CO}_{2}$, regression models were made from each chamber trial to develop predictive models to calculate the $\mathrm{CO}_{2}$ removed or generated after a 60 minute period. The data at the $60^{\text {th }}$ minute was used to compare species $\mathrm{CO}_{2}$ removal capacities. This was done by conducting a one factor ANOVA and Tukey's post hoc test (IBM SPSS Statistics Version 21, IBM Corp, Armonk, NY, USA).

\section{Results \& Discussion}

\subsection{Australian native plant species VOC removal efficiency}

There were significant differences amongst the native species benzene removal efficiencies $(\mathrm{P}=0.000$; Fig. 1). Specifically, Dianella had the highest SPRE of 59.04\% and Lomandra had the lowest removal efficiency of $39.96 \%$. The substrate only control SPRE was found to be significantly lower than only the Dianella $(\mathrm{P}=0.000)$ and Blechnum modules $(\mathrm{P}=0.004)$, indicative that soil microorganisms are the main site for VOC removal. Dianella benzene SPRE was significantly greater $(\mathrm{P}<0.05)$ than every species except Blechnum, which was the second most efficient species for benzene SPRE. The reason for these species having higher removal efficiencies is unknown and can not be attributed to their leaf or root morphologies.

In the current study, significant differences were observed between the native species' benzene removal efficiencies. In a similar experiment conducted previously (Irga et al. 2019), the VOC SPREs of 4 common ornamental species in active green walls were compared, also detecting species differences for both benzene and ethyl acetate removal efficiencies. The benzene removal efficiency range amongst species recorded by Irga et al. (2019) was relatively consistent, with $<15 \%$ variability amongst species, with SPRE ranging from 45.54-59.50\%. The ornamental species, $N$. glabra, was found to have the highest benzene removal efficiency, likely due to its high leaf wax content. In the current study, a similar range of benzene SPREs was found, indicating that the effects that Australian native species have on active green walls results in similar benzene removal efficiencies to common ornamental species. In the current study, the Dianella species was found to have the highest removal efficiency, whilst the Lomandra species had the lowest. The difference in removal efficiencies between these two species was surprising due to their similar morphologies, notably their similar leaf areas. 
VOC removal appears to be mainly due to substrate bacteria metabolising the VOCs as a source of carbon (Wood et al. 2002; Orwell et al. 2004; Irga et al. 2013). As such, differences amongst root morphological characteristics may facilitate increased microbial activity if these differences result in improved nutrient supply for soil microorganisms (Kim et al. 2018); which could in turn increase VOC removal efficiency. However, as the total residence time of the benzene within the active green wall systems was $<10$ minutes, it was probable that insufficient time for substantial microbial metabolism occurred, and instead VOC removal was likely to primarily be a simple sorption process (Irga et al. 2019). This hypothesis is supported by the absence of significant positive correlations between benzene removal efficiency and any of the plant leaf or root traits in both the current study and Irga et al.'s (2019) study. Further, Irga et al. (2019) recorded negative correlations between root surface area, root mass and root diameter and benzene removal; however, these correlations were fairly weak, with $\mathrm{r}<$ 0.7 in all cases. In the current study, no significant negative correlations were observed between benzene removal and any plant traits, indicating a consistent difference in root-plant relationships for Australian native plant species compared to ornamental taxa. We could not resolve the reason for this pattern from the current data, although it is possible that it results from the generally different environments from where the native species originate, as they are all predominantly shrubland species whilst ornamental species typically originate from rainforest understorey environments.

It was proposed by Irga et al. (2019) that VOC removal was dependent on hydrophilic adsorbent sites in the substrate, with increasing root mass, surface area and diameter associated with increased SPRE. In the current study however, no significant correlations were observed between any leaf or root trait and VOC SPRE. It has been proposed that leaf components allow an additional pathway for VOC removal via the stomata and cuticle (Gkorezis et al. 2016; Jindachot et al. 2018); with large leaf areas (Parseh et al. 2018) and stomatal uptake (Setsungnern et al. 2017) being characteristics influential on benzene removal. Further, the plant leaves and leaf-associated microbes have been implicated in the ability of a plant to remove VOCs (Wei et al. 2017).

It has additionally been hypothesised that different plant species can affect both physical and chemical substrate properties, thus altering the VOC removal (Deng and Deng, 2018). As no traits influenced benzene removal in the current study, it cannot be suggested which morphological traits would lead to higher benzene removal efficiencies. The absence of associations between morphological characteristics and VOC SPRE found in the current work may indicate that these mechanisms do not extend to Australian native plants. None the less, Dianella was found to be the most appropriate species for maximum benzene removal, and could provide valuable VOC removal effects when used in indoor botanical biofiltration systems. 


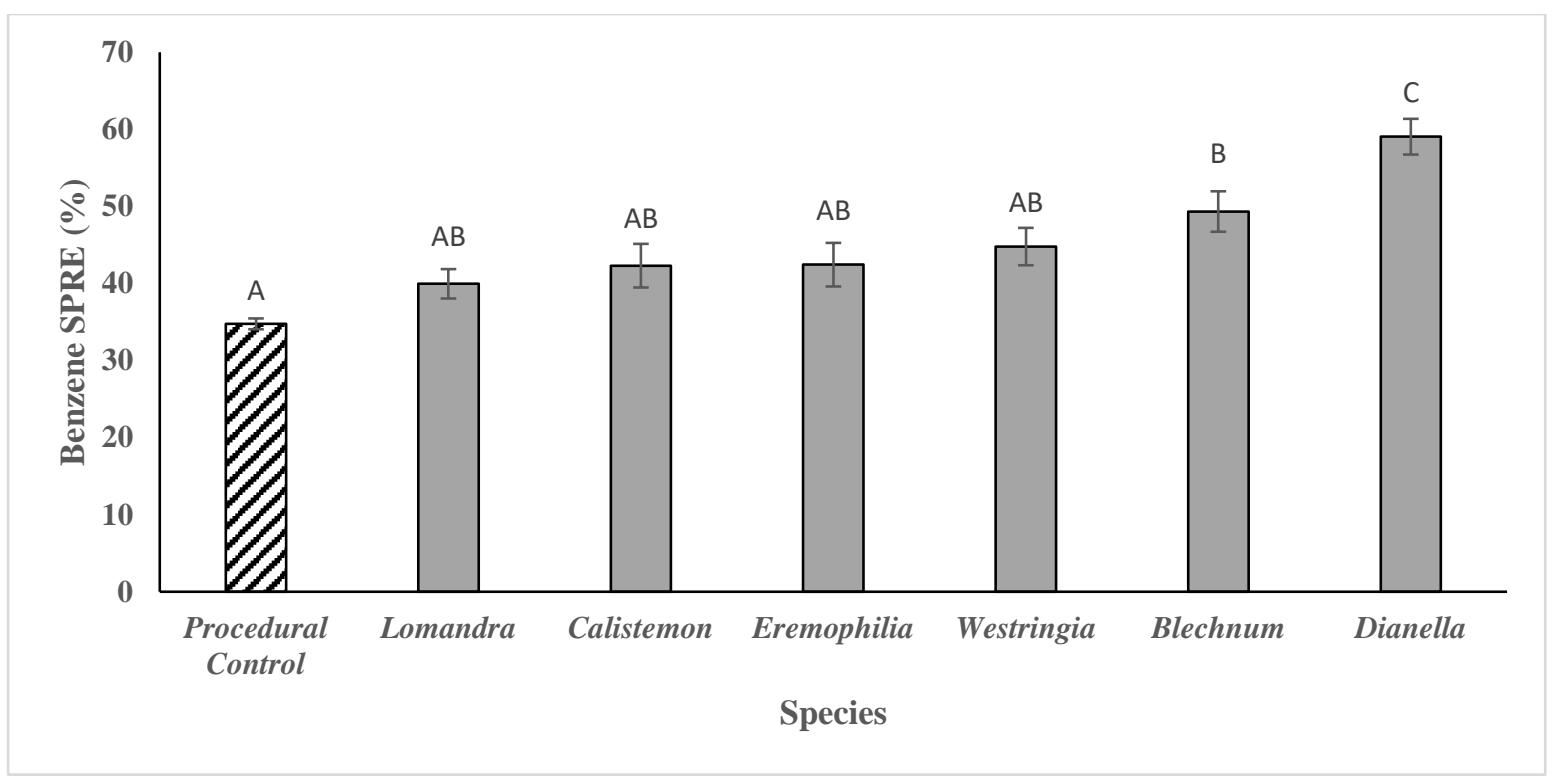

Figure 1: The different native species benzene single pass removal efficiencies; $n=4$, error bars are the standard error of the mean. Treatments with the same letter are not significantly different from each other ( $\mathrm{P}>0.05$ ANOVA).

\subsection{Australian native plant species PM removal efficiency}

There were no significant differences observed amongst species' SPREs for the PM size fractions: PM $_{1-}$ ${ }_{2.5}$; $\mathrm{PM}_{2.5-5}$ and $\mathrm{PM}_{5-10}(\mathrm{P}>0.05)$. For $\mathrm{PM}_{0.5-1}$, the only significant difference observed was between the Dianella and Eremophilia species $(\mathrm{P}=0.003)$. The smallest $\mathrm{PM}$ size fraction $\mathrm{PM}_{0.3-0.5}$, produced the greatest species differences. PM SPRE by the active green walls containing Callistemon species were found to be significantly different to every other species ( $\mathrm{P}<0.05)$, although the direction of these differences was variable (see Fig. 2) The Dianella and Lomandra species were both relatively inefficient at $\mathrm{PM}_{0.3-0.5}$ removal, filtering significantly less $\mathrm{PM}$ of this size fraction than every species except one another. As was the case in the study by Pettit et al. (2018), differences amongst SPREs for PM size fractions were also detected; with SPRE generally increasing as the PM size fractions increased.

In the current study, there were significant differences amongst native species' PM SPREs. In an equivalent study conducted by Pettit et al. (2017) testing ornamental plant species, considerable differences amongst different species' PM SPREs were found, with the fern, Nephrolepsis exaltata bostoniensis demonstrating the highest removal efficiencies of $45.78 \%$ and $92.46 \%$ for $\mathrm{PM}_{0.3-0.5}$ and $\mathrm{PM}_{5-10}$ respectively. In the current study, the active green wall plant species tested had generally lower removal efficiencies across all PM size fractions than the ornamental species tested by Pettit et al. (2017). Furthermore, Lee et al. (2015) determined that their green wall system had a $65-90 \%$ PM removal efficiency, which was also considerably greater than the native species removal efficiencies detected in the current study.

Pettit et al. (2017) noted the influence of root structure on the PM SPRE of active green walls, proposing that different root structures modified the structure and physiochemical properties of the substrate, which thus increased filtration capacity. More specifically, the simple, rhizomatous root systems produced by ferns and herbaceous species were associated with more effective filtration characteristics, compared to woody plants which typically have complex, branching root systems (Dong et al. 2015). In the current study however, no specific root features nor leaf traits were found to be correlated with high PM SPRE. Pettit et al. (2017) suggested that species which have leaves that grow horizontally, 
sitting at a perpendicular angle, allow greater foliar impaction, compared to species which have their leaves arranged at a more prominent vertical angle. Although the Callistemon had leaves which were arranged angularly upwards, potentially increasing the PM absorption area, it's performance in the current study was not different to the other species tested. Additionally, the Callistemon species was the only tested species which had leaf hairs, a known advantageous PM accumulating trait (Beckett et al. 2000; Sæbo et al. 2012; Leonard et al. 2016; Chen et al. 2017), which could be predicted to have an influence on the SPRE rate. Whilst these advantageous leaf structures are known to increase PM filtration efficiency, surprisingly all native species PM SPRE were similar to one another.

When grown vertically in green wall systems, the root structures of tree and other woody species may be restricted, unlike plants such as ornamental ferns that generally grow in dense colonies (Coelho et al. 2014; Large \& Farrington, 2016; Ng et al. 2016), which may have increased root competition effects (Pettit et al. 2017). In the current study, however, the Callistemon and Westringia species displayed a similar SPRE to the Blechnum fern and monocot shrub species tested. It is likely that this was a result of the considerable root morphological differences between Blechnum and the ornamentals tested by Pettit et al. (2017). This is evidence that plant influence on biofilter pollutant removal performance should not be generalized across broad taxonomic groupings, and individual species' performance should be tested in isolation. In conclusion, active botanical biofilters containing Australian native species were shown to be able to effectively reduce PM, with all tested species having similar SPRE values. However, the SPRE of the native species was lower than the previous recorded SPRE values of ornamental species.

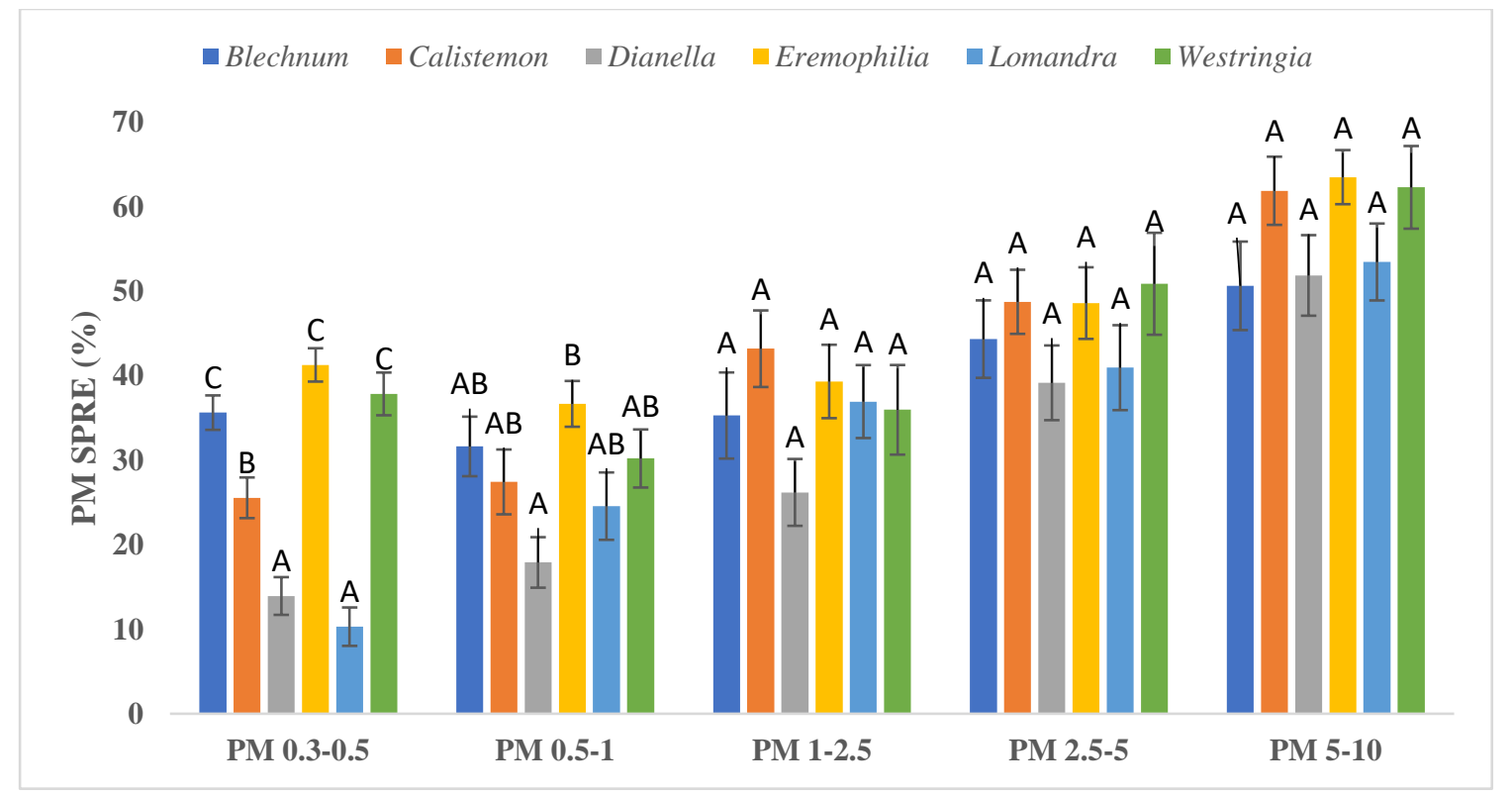

Figure 2: Australian native plant species' PM single pass removal efficiencies across different PM size fractions; $n=15$, error bars are the standard error of the mean. Treatments within each particle size fraction with the same letter are not significantly different from each other ( $>>0.05$ ANOVA).

\subsection{Australian native plant species $\mathrm{CO}_{2}$ removal efficiency}

The final concentration of $\mathrm{CO}_{2}$ for all species was significantly higher than the leakage data $(\mathrm{P}<0.05)$, indicative that all biofilters generated $\mathrm{CO}_{2}$ under the lighting conditions used. There were no significant differences between any species and the substrate only control treatments $(\mathrm{P}>0.05)$, indicating that soil microorganism respiration dominated the $\mathrm{CO}_{2}$ generation observed. Nonetheless, several significant 
differences were observed for the $\mathrm{CO}_{2}$ generation rate amongst species, with Eremophilia producing the greatest amount of $\mathrm{CO}_{2}$ and Blechnum producing the least $(\mathrm{P}=0.005)$. Eremophilia and Westringia also produced significantly more $\mathrm{CO}_{2}$ than Callistemon and Blechnum, respectively $(\mathrm{P}=0.032$ and $\mathrm{P}=$ 0.023 , respectively). There were no other significant differences amongst species $\mathrm{CO}_{2}$ removal efficiencies. As none of the native species tested were able to remove $\mathrm{CO}_{2}$ under the light levels used, it is unlikely that they would be of value for indoor phytoremediation use for this gas.

Pennisi and van Iersel (2012) noted that due to the low light levels of indoor environments, an impractical number of potted plants would be needed to make a significant impact to indoor $\mathrm{CO}_{2}$ levels. Torpy et al. (2014) further stated that for adequate $\mathrm{CO}_{2}$ removal, plants would have to be supplied with higher light levels than those generally used in situ, whilst nonetheless identifying plant-light level combinations that could lead to some reductions in indoor $\mathrm{CO}_{2}$. In the current study, none of the native species tested were capable of removing $\mathrm{CO}_{2}$ under the light levels used, in fact, all species increased the total $\mathrm{CO}_{2}$ concentration in the test chambers. This was due to respiration by the microorganisms located within the substrate (Somova and Pechurkin, 2001; Torpy et al. 2016). As all plants were exposed to natural sunlight conditions prior to the experiment commencement and also during the experiment when not being tested on it is not likely that the plants experience photo-inhibition from low light levels and this can not be attributed to the plants inability to reduce $\mathrm{CO}_{2}$ concentrations.

The photosynthetic photon flux density supplied to plants is a key determinant of the $\mathrm{CO}_{2}$ removal capacity of different plant species. Whilst the natives tested in the current study were ineffective for $\mathrm{CO}_{2}$ removal, Torpy et al. (2016) found that active green walls containing Chlorophytum comosum and Epipremnum aureum could remove some $\mathrm{CO}_{2}$ at light levels greater than $50 \mu \mathrm{mol} \mathrm{m} \mathrm{m}^{-2} \mathrm{~s}^{-1}$ (2375 lux), with more effective $\mathrm{CO}_{2}$ removed at higher light levels $\left(250 \mu \mathrm{mol} \mathrm{m} \mathrm{m}^{-2} \mathrm{~s}^{-1} ; 1875\right.$ lux $)$. The light levels used in the current study were significantly higher than both tested light levels in Torpy et al.'s (2016) study, and were considered sufficient to promote photosynthesis and $\mathrm{CO}_{2}$ removal by the Australian native plants tested, despite these species being known to require comparatively high light levels (Borthwick et al. 1952; Toole et al. 1955; Willis and Groves, 1991; Bell, 1993). The light source in the current study ranged from $1505.5 \mu \mathrm{mol} \mathrm{m} \mathrm{m}^{-2} \mathrm{~s}^{-1}$ at the uppermost foliage of the green wall to $111.6 \mu \mathrm{mol}$ $\mathrm{m}^{-2} \mathrm{~s}^{-1}$ at the bottom of the green wall. The light levels normally used in indoor environments range between 4-10 $\mu \mathrm{mol} \mathrm{m} \mathrm{m}^{1}$ (180-460 lux; Safe Work Australia, 2011), with the light levels used in the current study considered a practical maximum possible in indoor environments with the use of targeted plant location or plant-specific lighting systems. As the plant species tested in the current work were unable to remove $\mathrm{CO}_{2}$ at reasonable indoor photon flux densities, it is proposed that certain ornamental species will be more effective for $\mathrm{CO}_{2}$ removal in most indoor applications. 


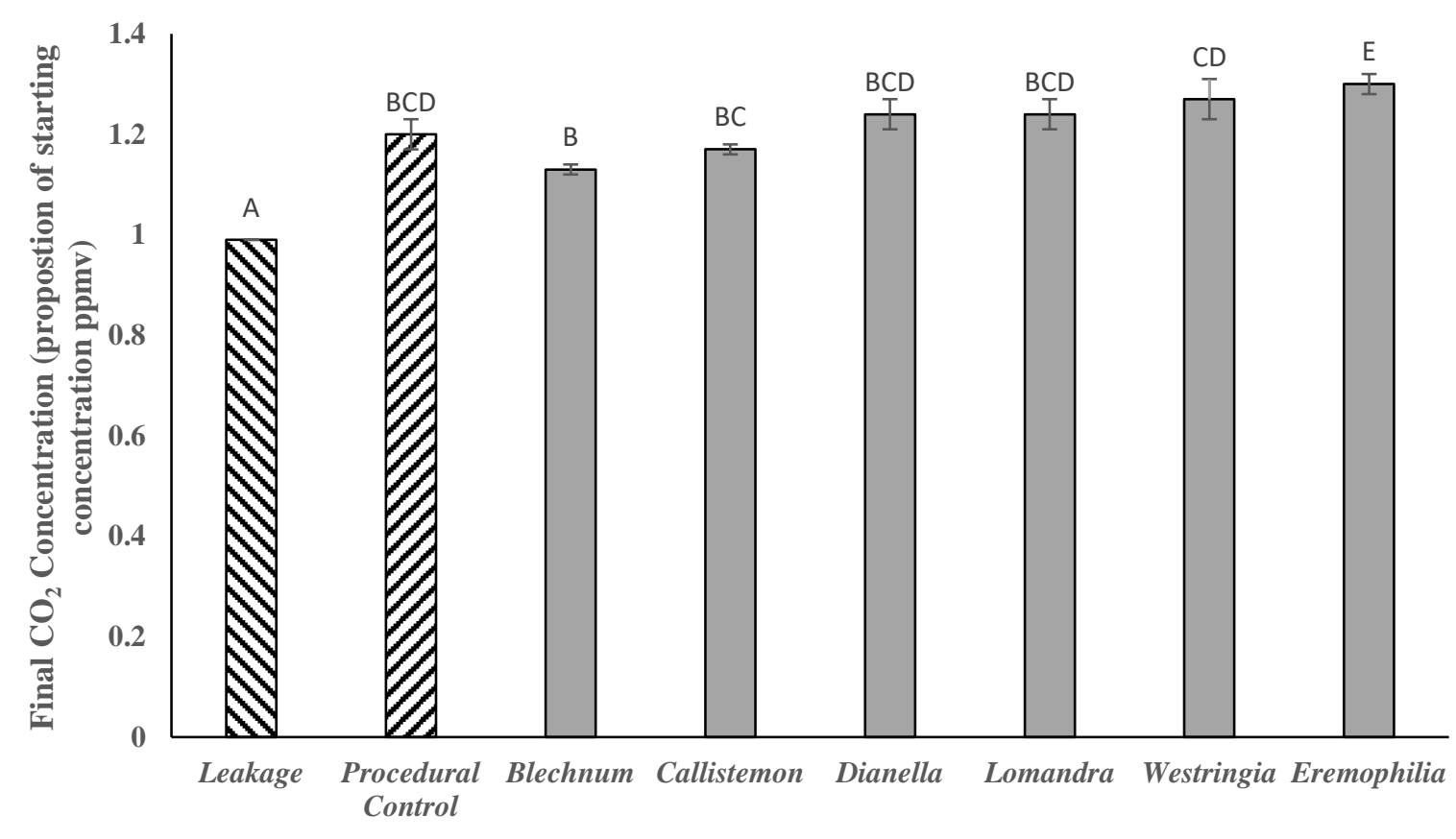

Species

Figure 3: The projected average final $\mathrm{CO}_{2}$ concentrations at the $60^{\text {th }}$ minute across the different Australian native species, displayed as the proportion of the starting concentration of $1000 \mathrm{ppmv}$. Data are means \pm the standard error of the mean, $n=3$. Treatments with the same letter are not significantly different from each other ( $\mathrm{P}>0.05$ ANOVA).

\subsection{Plant morphological data}

Leaf and root morphology was variable amongst species (Table 2), with significant differences observed amongst leaf widths, leaf areas, leaf fresh weights and leaf dry weights (all $\mathrm{P}=0.000$ ). There were also significant differences amongst the species' root diameters $(P=0.023)$. Figure 4 demonstrates the differences between the species' root morphologies.

Table 2: Australian native plant species leaf and root morphological traits. All data is representative of the respective traits within a singular green wall module, which contains 16 individual plants. Data are means \pm the SEM $(n=4)$.

\begin{tabular}{|c|c|c|c|c|c|c|c|c|}
\hline $\begin{array}{l}\text { Plant } \\
\text { Species }\end{array}$ & $\begin{array}{l}\text { Average } \\
\text { Leaf } \\
\text { Width } \\
(\mathrm{mm}) \\
\end{array}$ & $\begin{array}{l}\text { Leaf } \\
\text { Area }\left(\mathrm{m}^{2}\right)\end{array}$ & $\begin{array}{l}\text { Leaf Fresh } \\
\text { weight (g) }\end{array}$ & $\begin{array}{l}\text { Leaf Dry } \\
\text { Weight } \\
\text { (g) }\end{array}$ & $\begin{array}{l}\text { Average } \\
\text { Root } \\
\text { Diameter } \\
(\mathbf{m m}) \\
\end{array}$ & $\begin{array}{l}\text { Root Area } \\
\left(\mathbf{m}^{2}\right)\end{array}$ & $\begin{array}{l}\text { Root Fresh } \\
\text { Weight (g) }\end{array}$ & $\begin{array}{l}\text { Root Dry } \\
\text { Weight } \\
\text { (g) }\end{array}$ \\
\hline Blechnum & $\begin{array}{l}11.2 \pm \\
0.66\end{array}$ & $\begin{array}{l}359.2 \pm \\
0.25\end{array}$ & $\begin{array}{l}443 \pm \\
0.00\end{array}$ & $\begin{array}{l}52.9 \pm \\
0.00\end{array}$ & $\begin{array}{l}1.14 \pm \\
0.06\end{array}$ & $\begin{array}{l}14.48 \pm \\
9.23\end{array}$ & $\begin{array}{l}136 \pm \\
1.65\end{array}$ & $\begin{array}{l}19.6 \pm \\
0.23\end{array}$ \\
\hline Callistemon & $\begin{array}{l}7.06 \pm \\
0.18\end{array}$ & $\begin{array}{l}154.6 \pm \\
0.12\end{array}$ & $\begin{array}{l}418 \pm \\
0.00\end{array}$ & $\begin{array}{l}162 \pm \\
0.00\end{array}$ & $\begin{array}{l}1.58 \pm \\
0.19\end{array}$ & $\begin{array}{l}13.10 \pm \\
9.89\end{array}$ & $\begin{array}{l}107 \pm \\
0.60\end{array}$ & $\begin{array}{l}28.8 \pm \\
0.15\end{array}$ \\
\hline Dianella & $\begin{array}{l}15.0 \pm \\
0.46\end{array}$ & $\begin{array}{l}239.3 \pm \\
2.28\end{array}$ & $\begin{array}{l}632 \pm \\
0.07\end{array}$ & $\begin{array}{l}172 \pm \\
0.02\end{array}$ & $\begin{array}{l}1.17 \pm \\
0.07\end{array}$ & $\begin{array}{l}24.01 \pm \\
5.15\end{array}$ & $\begin{array}{l}198 \pm \\
1.09\end{array}$ & $\begin{array}{l}30.6 \pm \\
0.14\end{array}$ \\
\hline
\end{tabular}




\begin{tabular}{|l|l|l|l|l|l|l|l|l|}
\hline Eremophilia & $10.1 \pm$ & $364.6 \pm$ & $1278 \pm$ & $301 \pm$ & $1.34 \pm$ & $6.30 \pm$ & $49.6 \pm$ & $15.6 \pm$ \\
& 0.34 & 0.12 & 0.00 & 0.00 & 0.14 & 6.05 & 0.46 & 0.20 \\
\hline Lomandra & $10.3 \pm$ & $238.4 \pm$ & $1499 \pm$ & $721 \pm$ & $1.24 \pm$ & $1.63 \pm$ & $129 \pm$ & $37.6 \pm$ \\
& 0.30 & 2.71 & 0.26 & 0.07 & 0.10 & 12.5 & 0.73 & 0.26 \\
& & & & & & & & \\
\hline Westringia & $3.88 \pm$ & $301.7 \pm$ & $792 \pm$ & $193 \pm$ & $1.04 \pm$ & $26.04 \pm$ & $96.0 \pm$ & $21.7 \pm$ \\
& 0.10 & 0.03 & 0.00 & 0.00 & 0.08 & 6.51 & 1.07 & 0.11 \\
\hline
\end{tabular}

A

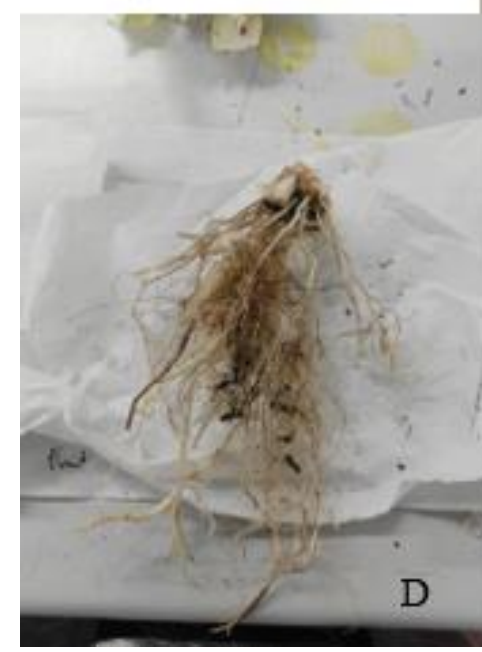

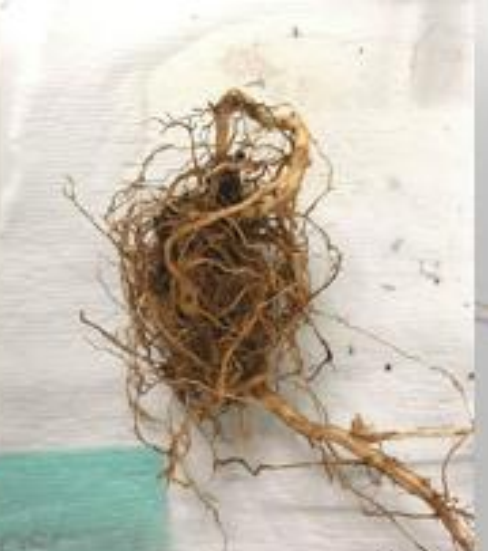

B

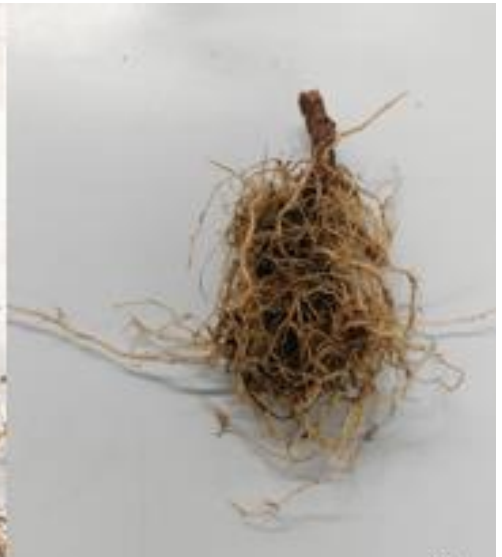

$\mathrm{C}$
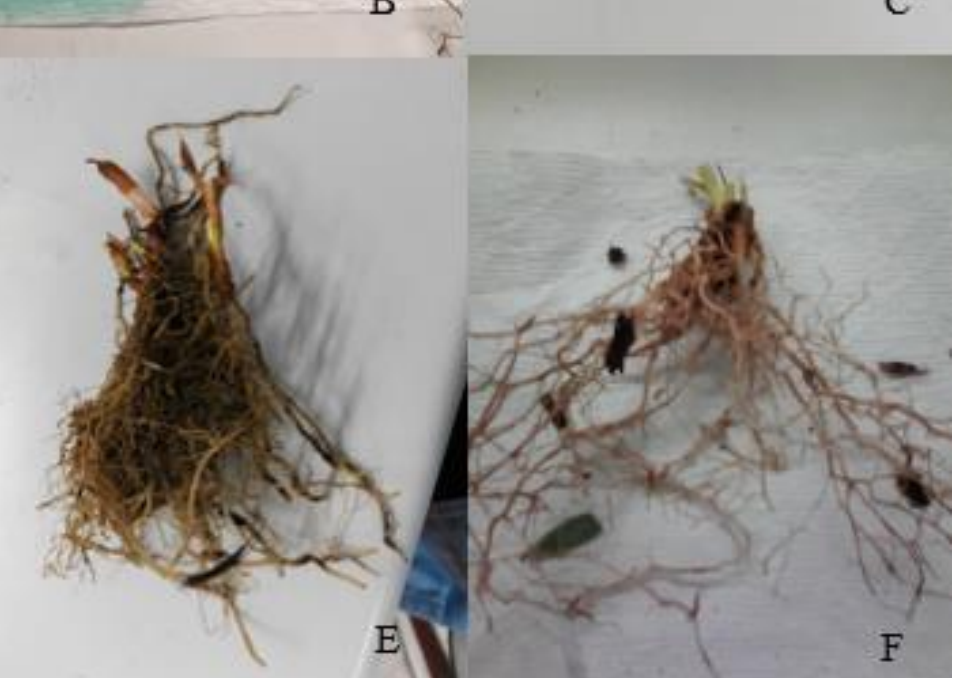

E

Figure 4: Root structures of the tested species. A: Blechnum, B: Callistemon, C: Westringia, D: Lomandra, E: Dianella, F: Eremophilia.

\subsection{Associations between plant morphological traits and pollutant removal efficiencies}

No leaf nor root morphological trait was found to be significantly correlated with $\mathrm{VOC}, \mathrm{CO}_{2}$ or PM removal efficiencies (all $\mathrm{P}$ values $>0.05$; Table 3 ).

Table 3: Correlation analysis between plant morphological traits and the different removal efficiencies for the three tested pollutants. TSP $=$ total suspended particulates. 


\begin{tabular}{|l|l|l|l|l|l|l|l|l|l|}
\hline $\begin{array}{l}\text { Pollutant } \\
\text { Type }\end{array}$ & $\begin{array}{l}\text { Statistical } \\
\text { Result }\end{array}$ & $\begin{array}{l}\text { Leaf } \\
\text { width }\end{array}$ & $\begin{array}{l}\text { Leaf } \\
\text { area }\end{array}$ & $\begin{array}{l}\text { Leaf } \\
\text { fresh } \\
\text { weight }\end{array}$ & $\begin{array}{l}\text { Leaf } \\
\text { dry } \\
\text { weight }\end{array}$ & $\begin{array}{l}\text { Root } \\
\text { diameter }\end{array}$ & $\begin{array}{l}\text { Root } \\
\text { area }\end{array}$ & $\begin{array}{l}\text { Root } \\
\text { fresh } \\
\text { weight }\end{array}$ & $\begin{array}{l}\text { Root } \\
\text { dry } \\
\text { weight }\end{array}$ \\
\hline \multirow{2}{*}{ VOC } & $\mathrm{P}$ & 0.496 & 0.601 & 0.572 & 0.560 & 0.754 & 0.135 & 0.355 & 0.156 \\
\cline { 2 - 10 } & $r$ & 0.351 & -0.273 & -0.294 & -0.303 & 0.166 & -0.682 & -0.463 & -0.659 \\
\hline \multirow{2}{*}{$\mathrm{CO}_{2}$} & $\mathrm{P}$ & 0.717 & 0.118 & 0.112 & 0.110 & 0.650 & 0.241 & 0.780 & 0.306 \\
\cline { 2 - 9 } & $r$ & 0.191 & 0.705 & 0.713 & 0.715 & -0.238 & 0.567 & 0.148 & 0.506 \\
\hline \multirow{2}{*}{$\mathrm{TSP}$} & $\mathrm{P}$ & 0.180 & 0.069 & 0.143 & 0.143 & 0.803 & 0.102 & 0.064 & 0.051 \\
\cline { 2 - 9 } & $r$ & 0.630 & 0.778 & 0.673 & 0.672 & 0.132 & 0.727 & 0.787 & 0.809 \\
\hline
\end{tabular}

\section{Conclusion}

It is important to note that the results obtained in the current study can only provide an indication on the removal efficiency of the plant species tested, due to the unrealistic conditions of chamber studies. Chamber studies cannot realistically be extrapolated to real world building environments (Llewellyn and Dixon, 2011; Irga et al., 2013; Soreanu et al., 2013) due to the plant density per unit volume of experimental chamber atmosphere being higher than would be possible in buildings (Torpy et al., 2015). The results obtained from laboratory chamber pull down experiments are thus not often projected into real-world situations due to the complex dynamics of indoor settings (Llewellyn and Dixon, 2011). None-the-less the results obtained in the current study provide an indication on the more efficient species for different pollutant removal, which could be tested in in situ conditions to provide a more realistic removal capacity.

The current findings highlight the importance of plant species selection in active phytoremediation systems for maximum pollutant removal efficiency. The Australian native species tested here were shown to be effective at removing benzene, with similar SPRE values to ornamental species. Dianella was found to remove the greatest amount of benzene, although the characteristics of this species leading to its greater efficiency were not resolved by the current work. The native species were also capable of reducing PM, however, at lower efficiencies than previously tested ornamental species. All tested native species were shown to be inefficient for the reduction of $\mathrm{CO}_{2}$ at the supplied light levels, in contrast to previously tested ornamental species. As has been the case in previous work, pollutant removal characteristics were inconsistent amongst species. Whilst Dianella was found to be the highest performing species for benzene removal, it was the lowest performing species regarding PM filtration, indicating that plant species selection should focus on the dominant pollutant in any specific application. It is recommended that future studies focus on accurate biofilter species selections based on the pollutants of concern. It is thus suggested that ornamental species remain the most appropriate choices for active biofilter phytoremediation use in indoor applications, due to their higher and more consistent removal efficiencies for most pollutants. This does not negate the potential of Australian native species, however, as their tolerance of harsh environmental conditions may lead to high value applications in outdoor biofiltration applications. Further work, notably field trials in varied environments, will thus be required before strong recommendations of plant species selection can be made for all conditions.

\section{References:}


Abbass OA, Sailor DJ, Gall ET (2017) Effectiveness of indoor plants for passive removal of indoor ozone. Building and Environment. 119:62-70. doi: https://doi.org/10.1016/j.buildenv.2017.04.007

Abdo P, Huynh BP, Avakian V, Nguyen T, Torpy FR, Irga PJ (2016) Measurement of air flow through a green-wall module. Australasian Fluid Mechanics Conference, 5-8 December 2016 Perth, Australia.

ASHRAE (2011) GreenGuide: the design, construction, and operation of sustainable buildings, 3rd edn. ASHRAE, Atlanta.

Aydogan A, Montoya LD (2011) Formaldehyde removal by common indoor plant species and various growing media. Atmospheric Environment. 45:2675-82. doi: 10.1016/j.atmosenv.2011.02.062

Beckett P, Free-Smith P, Taylor G (2000) Effective tree species for local air-quality management. Journal of Arboriculture. 26:12-9.

Beecham S, Razzaghmanesh M, Bustami R, Ward J (2019) The role of green roofs and living walls as WSUD approaches in a dry climate. In: Sharma, A.K., Gardner, T. and Begbie, D. (eds) Approaches to water sensitive urban design, Woodhead publishing, pp. 409-430.

Bell DT (1993), Germination responses to variations in light quality of eight species from sandy habitats in Western Australia. Australian Journal of Botany. 41:321-326.

Borthwick HA, Hendricks SB, Parker MW, Toole EH, Toole VK. (1952) A reversible photoreaction controlling seed germination. Proceedings of the National Academy of Science, USA. 28: 662-666.

Brodribb T, Hill RS (1993) A physiological comparison of leaves and phyllodes in Acacia melanoxylon. Australian Journal of Botany. 41: 293-305.

Brown SK, Sim MR, Abramson MJ, Gray CN (1994) Concentrations of Volatile Organic Compounds in Indoor Air - A Review. Indoor Air. 4:123-134.

Brown SK (1997) Indoor air quality, Australia: State of the Environment Technical Paper Series (Atmosphere), Department of the Environment, Sport and Territories, Canberra.

Chen W, Zhang JS, Zhang Z (2005) Performance of air cleaners for removing multiple volatile organic compounds in indoor air. ASHRAE Transactions. 111:1101-1104.

Chen L, Liu C, Zou R, Yang M, Zhang Z (2016) Experimental examination of effectiveness of vegetation as bio-filter of particulate matters in the urban environment Environmental Pollution. 208:198-208.

Chen L, Liu C, Zhang L, Zou R, Zhang Z (2017) Variation in tree species ability to capture and retain airborne fine particulate matter $\left(\mathrm{PM}_{2.5}\right)$. Scientific Reports. 7: 3206. doi: 10.1038/s41598-017-03360-1

Coelho LFM, Ribeiro MC, Pereira RAS (2014) Water availability determines the richness and density of fig trees within Brazilian semideciduous forest landscapes. Acta Oecologica. 57:109-116.

Darlington A, Dat J, Dixon M (2001) The biofiltration of indoor air: air flux and temperature influences the removal of toluene, ethylbenzene, and xylene. Environmental Science \& Technology. 35:240-246.

Deng L, Deng Q (2018) The basic roles of indoor plants in human health and comfort. Environmental Science \& Pollution Research. 25: 36087-36101. doi:10.1007/s11356-018-3554-1

Dong X, Wang H, Gu J, Wang Y, Wang Z (2015) Root morphology, histology and chemistry of nine fern species (pteridophyta) in a temperate forest. Plant \& Soil. 393:215-227.

Fowler D (2002) Pollutant deposition and uptake by vegetation. In: Bell JNB, Treshow M. (Eds.). Air Pollution and Plant Life. Second Edition, p. 43. 
Gawrońska H, Bakera B (2015) Phytoremediation of particulate matter from indoor air by Chlorophytum comosum L. plants. Air Quality, Atmosphere \& Health. 8:265-272.

Gkorezis P, Daghio M, Franzetti A, Van Hamme JD, Sillen W, Vangronsveld J (2016) The interaction between plants and bacteria in the remediation of petroleum hydrocarbons: an environmental perspective. Frontiers in Microbiology. 7: 1836.

Godish T, Guindon C (1989) An assessment of botanical air purification as a formaldehyde mitigation measure under dynamic laboratory chamber conditions. Environmental Pollution. 62:13-20.

Hosker RP, Lindberg SE (1982) Review: atmospheric deposition and plant assimilation of gases and particles. Atmospheric Environment.16:889-910.

Irga PJ, Paull NJ, Abdo P, Torpy FR (2017) An assessment of the atmospheric particle removal efficiency of an in-room botanical biofilter system. Building \& Environment. 115:281-290.

Irga PJ, Pettit T, Irga RF, Paull NJ, Douglas ANJ, Torpy FR (2019) Does plant species selection in functional active green walls influence VOC phytoremediation efficiency?. Environmental Science and Pollution Researc. 26:12851-12858.

Irga PJ, Torpy FR, Burchett MD (2013) Can hydroculture be used to enhance the performance of indoor plants for the removal of air pollutants?. Atmospheric Environment. 77:267-271.

Jindachot W, Treesubsuntorn C, Thiravetyan P (2018) Effect of individual/co-culture of native Phyllosphere organisms to enhance Dracaena sanderiana for benzene phytoremediation. Water Air \& Soil Pollution. 229:80. doi:10.1007/s11270-018-3735-z

Kim KJ, Il Jeong M, Lee DW, Song JS, Kim HD, Yoo EH, Jeong SJ, Han SW, Kays SJ, Lim YW, HH K. (2010) Variation in formaldehyde removal efficiency among indoor plant species, Horticultural Science. 45:1489-1495.

Kim KJ, Khalekuzzaman M, Suh JN, Kim HJ, Shagol C, Kim H-H, Kim HJ (2018) Phytoremediation of volatile organic compounds by indoor plants: a review Horticulture, Environment, and Biotechnology 59:143-157 doi:10.1007/s13580-018-0032-0

Kim KJ, Kim HJ, Khalekuzzaman M, Yoo EH, Jung HH, Jang HS (2016) Removal ratio of gaseous toluene and xylene transported from air to root zone via the stem by indoor plants Environmental Science \& Pollution Research 23:6149-6158.

Kooyman RM, Laffan SW, Westoby M (2017) The incidence of low phosphorus soils in Australia Plant Soil 412:143-150 doi:10.1007/s11104-016-3057-0

Large M, Farrington L (2016) The Nephrolepis Boston fern complex (including Nephrolepis exaltata [L.] Schott), Nephrolepidaceae, naturalised in New Zealand

Lee C, Choi B, Chun M (2015) Stabilization of soil moisture and improvement of indoor air quality by a plant-biofilter integration system Korean Journal of Horticultural Science \& Technology 33:751-762

Leonard RJ, McArthur C, Hochuli DF (2016) Particulate matter deposition on roadside plants and the importance of leaf trait combinations Urban Forestry \& Urban Greening 20:249-253 doi:https://doi.org/10.1016/j.ufug.2016.09.008

Lin MW, Chen LY, Chuah YK (2017) Investigation of a potted plant (Hedera helix) with photoregulation to remove volatile formaldehyde for improving indoor air quality. Aerosol and Air Quality Research 17:2543-54. 
Litschke T, Kuttler WJ (2008) On the reduction of urban particle concentration by vegetation-a review Meteorolgische Zeitschrift 17:229-240.

Lohr VL, Pearson-Mims CH, Goodwin GK (1996) Interior plants may improve worker productivity and reduce stress in a windowless environment Journal of Environmental Horticulture 14:97-100

Massa GD, Kim H-H, Wheeler RM, Mitchell CA (2008) Plant productivity in response to LED lighting Horticultural Science 43:1951-1956

Montgomery JF, Green SI, Rogak SN, Bartlett K (2012) Predicting the energy use and operation cost of HVAC air filters Energy and Buildings 47:643-650 doi:https://doi.org/10.1016/j.enbuild.2012.01.001

Ng CWW, Ni JJ, Leung AK, Zhou C, Wang ZJ (2016) Effects of planting density on tree growth and induced soil suction Géotechnique 66:711-724 doi:10.1680/jgeot.15.P.196

Orwell RL, Wood RA, Tarran J, Torpy F, Burchett MD (2004) Removal of benzene by the indoor plant/substrate microcosm and implications for air quality Water, Air, \& Soil Pollution 157:193-207

Ottelé M, van Bohemen HD, Fraaij A (2010) Quantifying the deposition of particulate matter on climber vegetation on living walls Ecological Engineering 36:154-162

Parseh I, Teiri H, Hajizadeh Y, Ebrahimpour K (2018) Phytoremediation of benzene vapors from indoor air by Schefflera arboricola and Spathiphyllum wallisii plants Atmospheric Pollution Research 9:10831087

Pasquet-Kok J, Creese C, Sack L (2010) Turning over a new 'leaf': multiple functional significances of leaves versus phyllodes in Hawaiian Acacia koa Plant, Cell and Environment 33:2084-2100

Pennisi SV, van Iersel MW (2012) Qunatification of Carbon Assimilation of Plants in Simulated and In Situ Interiorscapes Hortscience 47:468-476

Petroff A, Mailliat A, Amielh M, Anselmet FJ (2008) Aerosol dry deposition on vegetative canopies. Part II: A new modelling approach and applications Atmospheric Environment 42:3654-3683

Pettit T, Irga PJ, Abdo P, Torpy FR (2017) Do the plants in functional green walls contribute to their ability to filter particulate matter? Building and Environment 125:299-307 doi:https://doi.org/10.1016/j.buildenv.2017.09.004

Ram SS et al. (2014) Plant canopies: bio-monitor and trap for re-suspended dust particulates contaminated with heavy metals Mitigation and Adaptation Strategies for Global Change 19:499-508 doi:10.1007/s11027-012-9445-8

Redlich C, Sparer J, Cullen M (1997) Sick-building syndrome Lancet 349:1013-1016

Sæbø A, Popek R, Nawrot B, Hanslin HM, Gawronska H, Gawronski SW (2012) Plant species differences in particulate matter accumulation on leaf surfaces Science of The Total Environment 427428:347-354 doi:http://dx.doi.org/10.1016/j.scitotenv.2012.03.084

Safe Work Australia (2011) Managing the work environment and facilities: code of practice, Safe Work Australia,

Canberra. https://www.safeworkaustralia.gov.au/system/files/documents/1702/managing work environment an d_facilities2.pdf

Schenk HJ, Jackson R (2002) The global biogeography of roots Monographs 72:311-328 
Setsungnern A, Treesubsuntorn C, Thiravetyan P, biochemistry (2017) The influence of different light quality and benzene on gene expression and benzene degradation of Chlorophytum comosum Plant Physiology \& Biochemistry 120:95-102

Singh S, Verma A (2007) Phytoremediation of air pollutants: a review. In: Environmental bioremediation technologies. Springer, Berlin, Heidelberg, pp 293-314

Somova LA, Pechurkin NS (2001) Functional, regulatory and indicator features of microorganisms in man-made ecosystems Advances in Space Research 27:1563-1570.

Sprent JI, Ardley J, James EK (2017) Biogeography of nodulated legumes and their nitrogen-fixing symbionts New Phytologist 215:40-56

Sternberg T, Viles H, Cathersides A, Edwards M (2010) Dust particulate absorption by ivy (Hedera helix L.) on historic walls in urban environments Science of the Total Environment 409:162-168.

Su YM, Lin CH (2015) Removal of indoor carbon dioxide and formaldehyde using green walls by bird nest fern Journal of Horticulture 84:69-76.

Sulpice R et al. (2014) Low levels of ribosomal RNA partly account for the very high photosynthetic phosphorus-use efficiency of P roteaceae species Plant Cell and Environment 37:1276-1298

Thompson JD (2005) Plant evolution in the Mediterranean, Oxford University Press, Oxford, UK.

Toole EH, Toole VK, Borthwick HA, Hendricks SB (1955) Interaction of temperature and light on germination of seeds Plant Physiology. 30:473-478.

Torpy FR, Irga PJ, Burchett MD (2014) Profiling indoor plants for the amelioration of high CO2 concentrations Urban Forestry \& Urban Greening 13:227-233 doi:http://dx.doi.org/10.1016/j.ufug.2013.12.004

Torpy FR, Irga PJ, Burchett MD (2015) Reducing Indoor Air Pollutants Through Biotechnology. In: Pacheco Torgal F, Labrincha JA, Diamanti MV, Yu CP, Lee HK (eds) Biotechnologies and Biomimetics for Civil Engineering. Springer International Publishing, pp 181-210. doi:10.1007/978-3319-09287-4_8

Torpy FR, Irga PJ, Moldovan D, Tarran J, Burchett MD (2013) Characterization and biostimulation of benzene biodegradation in the potting-mix of indoor plants Journal of Applied Horticulture 15:10-15

Torpy FR, Zavattaro M, Irga PJ (2017) Green wall technology for the phytoremediation of indoor air: a system for the reduction of high CO2 concentrations Air Qual Atmos Health 10:575-585 doi:10.1007/s11869-016-0452-x

Ullmann I (1989) Stomatal conductance and transpiration of Acacia under field conditions: similarities and differences between leaves and phyllodes Structure and Function of Trees 3:45-56,

Wang Z, Zhang JS (2011) Characterization and performance evaluation of a full-scale activated carbonbased dynamic botanical air filtration system for improving indoor air quality Building and Environment 46:758-768 doi:10.1016/j.buildenv.2010.10.008

Wang Z, Pei J, Zhang JS (2014) Experimental investigation of the formaldehyde removal mechanisms in a dynamic botanical filtration system for indoor air purification Journal of Hazardous Materials 280:235-243 doi:http://dx.doi.org/10.1016/j.jhazmat.2014.07.059

Front. Plant Sci., 28 July 2017 | https://doi.org/10.3389/fpls.2017.01318 
Willis AJ, Groves RH (1991) Temperature and light effects on the germination of seven native forbs Australian Journal of Botany 39:219-228

Wolverton BC, McDonald RC, Watkins Jr EA (1984) Foliage Plants for Removing Indoor Air Pollutants from Energy-Efficient Homes Economic Botany 38:224-228

Wolverton BD, Wolverton JD (1993) Plants and soil microorganisms: removal of formaldehyde, xylene and ammonia from the indoor environment Journal of the Mississippi Academy of Sciences 38:11-15.

Wood RA, Burchett MD, Alquezar R, Orwell RL, Tarran J, Torpy F (2006) The potted-plant microcosm substantially reduces indoor air VOC pollution: I. Office field-study Water, Air, \& Soil Pollution 175:163-180

Wood RA, Orwell RL, Tarran J, Torpy F (2002) Potted plant-growth media: interactions and capacities in removal of volatiles from indoor air Journal of Environmental Horticulture and Biotechnology $77: 120-129$

Wright IJ, Reich P, Westoby M (2001) Strategy shifts in leaf physiology, structure and nutrient content between species of high-and low-rainfall and high-and low-nutrient habitats Journal of Functional Ecology 15:423-434 